\title{
Impact of Green Supply Chain Managerial Practices on Environmental Sustainability: Readymade Garment Factories of Bangladesh
}

\author{
Farhana Ferdousi Aziz ${ }^{1}$, Tahmina Sultana ${ }^{1} \&$ Farhana Yasmin ${ }^{2}$ \\ 1 Department of Business Administration in Management Studies, Bangladesh University of Professionals, \\ Bangladesh \\ 2 Department of Business Administration in Finance and Banking, Bangladesh University of Professionals, \\ Dhaka, Bangladesh
}

Correspondence: Farhana Ferdousi Aziz, Department of Business Administration in Management Studies, Bangladesh University of Professionals, Bangladesh. E-mail: farhana.aziz210@gmail.com

Received: March 17, 2020

doi:10.5539/ijbm.v15n6p31
Accepted: April 11, 2020

Online Published: May 11, 2020

URL: https://doi.org/10.5539/ijbm.v15n6p31

\begin{abstract}
The purpose of this paper is to find out the impact of Green Supply Chain managerial practices on environmental sustainability in the garment factories of Bangladesh. A combination of qualitative and quantitative methods has been used to gather data through a survey. The survey respondents were mid-level SCM managers of 60 garment factories located in Gazipur. Descriptive data analysis, regression model and ANOVA have been used to show the impact of the independent variables on 'Environmental Sustainability'. This paper has revealed that 4 variables have a statistically significant relation with the dependent variable and that lack of knowledge and government initiatives are the main reasons for low environmental sustainability. The research identifies the government initiatives that need to be taken and it also claims that there should be awareness about the significance of environmental sustainability among managers and the workforce to achieve environmental sustainability. This is important for Bangladesh, because environmental sustainability has a positive impact on the economy of the country. Previous literature has shown the benefits of GSCM and its impact on environmental sustainability in other countries. Whereas, this paper shows the current GSCM practices of the readymade garment factories of Bangladesh and shows the impact of the practices on Environmental Sustainability. The paper shows the practices that have positive and negative impact on the sustainability of the environment and it also comes up with the reasons why certain practices have a negative impact. Thus, this will help the government of Bangladesh to know about the practices that need to be continued and those that need to be improved.
\end{abstract}

Keywords: supply chain managerial practices, green SCM practices, environmental sustainability

\section{Introduction}

The management sector of Bangladesh's garment factories is dealing with a challenging but promising issue of environmentalism which has come into attention due to certain treaties to fight climate change. This environmentalism has pressurized factories to come up with practices and procedures that will help make companies greener. In addition to financial factors, now companies also have prioritized environmental factors and keep a balance between the factors (Al Mamun, 2019). Nowadays environmentalism is been paid a lot of attention by the government of Bangladesh because it has been found that it carries a huge potential in achieving environmental goals. The environmental management aspects have been integrated with Supply Chain Management practices, due to which Supply Chain Management was named to Green Human Resource Management (GHRM).

GSCM is about the policies, practices that make companies greener by making them take the responsibility of carbon emission, in order to benefit the individual, society, natural environment and the business (Liu, C. et. al, 2016). The functions of GSCM are comprised of Green Procurement, Green Manufacturing, Green Distribution and Green Logistics. These functions will be used as the independent variables of the paper. Following are the explanations of the variables: 
Green Procurement: is one of the supply-side practices based on which suppliers are chosen. Suppliers are chosen depending on their environmental competence, technical and eco-design capability, environmental performance, etc.

Green Manufacturing: manufacturers manufacture products in a way that help to reuse, recycle and recover parts and material components of the product; avoid or reduce the use of materials, which will harm the environment, within production process; etc.

Green distribution: a type of packaging that makes the attempt to (1) downsize packaging, (2) use "green" packaging materials, (3) promote recycling and reuse programs, etc.

Green logistics: is about delivering goods directly to user site, using alternative fuel vehicles and grouping orders together, etc. Green logistic is also about reverse logistic which means that companies will collect used products and packaging from customers for recycling, returning packaging and products to suppliers for reuse and so on.

The aim of this paper is to find out the type of supply chain managerial practices of garment factories of Bangladesh that will help to sustain the environment and see the actual impact of those practices on environmental sustainability. If the impact is seen to be low and not as anticipated, then the paper will try to come up with the reasons for this low impact.

This paper is significant because Bangladesh is in its early stage of developing environmental sustainability and the concept of Green SCM is quite new for the SCM department of factories. Besides, it is an area that has not been researched much. Therefore, this paper will be beneficial for Bangladesh, which will help to identify the gaps in achieving environmental sustainability. Moreover, environmental sustainability not only reduces carbon footprints and conserve natural resources of the country but also will help to boost the economy of the country. Research has shown that going green has a direct impact on profits of businesses and truly improves return on investments. Thus, this paper will serve to be crucial for the government of Bangladesh.

\section{Literature Review}

This research by Tumpa et al. (2019), examines the views and barriers in implementing green supply chain managerial practices in the textile factories of Bangladesh. A survey was carried out and its respondents were textile experts of operations and supply chain division. The survey was carried out to find out the barriers that companies have to face in implementing GSCM. It is found that financial limitations, absence of top management commitment, and difficulty in supply chain are the most significant barriers for some of the practitioners, and so on are the usually recognized important barriers towards green supply chain implementation in the textile industry of Bangladesh.

This research, by Yadlapalli, Rahman, and Gunasekaran (2018) shows supplier selection and supplier development as the governance mechanisms of social responsibility and it brings forward the question of how social responsibility can be applied at the manufacturing factories of the apparel producers in the setting of global apparel supply chains. The outcomes suggest that the mechanisms, supplier selection and supplier development have a positive effect on the environmental and social performance of the supplier firm and perform as a factor that drives the application of social responsibility.

The aim of this paper is to examine the impact of green supply chain managerial practices on environmental sustainability in readymade garment factories. According to its researchers, Hossain, et al. (2016), RMG manufacturing is one of the appropriate examples of the supply chain management. The study reveals that the decision makers and planners of RMG should bring into line their supply chain strategies, work together with all the supply chain partners, share information among the stages of supply chain, have a standard SCM procedure, fulfill the code of conduct, etc.

According to Ahmed, Akter, and Ma's paper, pollution has pressurized textile companies to come up with eco-friendly skills. Thus, this paper shows the types of green supply chain managerial practices that textile factories employ in their textile factories in Gazipur district. Bangladesh holds the second position as a garment exporter country, however, its EPI-2018 (Environmental Performance Index) rank of Bangladesh is the worst. It was 179 out of 180 internationally and 26th in Asia, which is the lowest. This means that awareness of GSCM is very poor, so the paper says that it is very important to spread the knowledge of GSCM among employees of factories and implement it as early as possible.

The purpose of this paper by Habib, and Bao (2019), is to find the impact of knowledge management capability (KMC) on green supply chain management (GSCM) practices which in turn has an impact on firm performance. The study exposed that KMC has an important positive effect on internal and external GSCM practices adoption. Finally, this study shows that KMC can bring sustainable performance through GSCM practices. The paper also 
shows the importance of GSCM in developing sustainability performance.

The objective of Bouzon and Govindan's, study in 2015, is to find out the most important drivers of reverse logistics in the Brazilian textile industry and then rank the drivers based on their level of importance. The ranking was done using Analytical Hierarchy Process (AHP) approach. The study offers some valuable outcomes: the most important drivers for RL practice are policy and economic related issues.

The key purpose of the study by Köksal, Strähle, Müller and Freise in 2017, is to concentrate on the social matters in sustainable supply chain management (SSCM) by considering the textile/apparel sector as the field of application. The study shows that no investigation has been carried out before in this field. Results show that a company's internal orientation is the main supporting factor in sustainable supply chain management practices

Objective of this paper, by Faisal Alam in 2019, is to disclose the best selection of raw materials and means of production, taking environmental sustainability into account. In the findings better substitutes of fibre selection and ways of delivering the final product have been presented. Through these alternatives, the supply chain of garment industry are made greener.

Hong, Zhang and Ding's study, published in 2018, empirically examines the influence of Sustainable Supply Chain Management (SSCM) practices on supply chain (SC) dynamic capabilities and enterprise performance (comprising economic, environmental and social performance) by clearly concentrating on the mediation effect of SC dynamic capabilities on the link between SSCM practices and enterprise performance. The results reveal that SSCM practices have an important positive effect on SC dynamic capabilities and all three aspects of performances.

Today, including sustainability into the supply chain has become an important issue for many textile and apparel companies. Usual tactics comprise sustainable product strategy, sustainable investment, sustainable performance evaluation, etc. that contribute to the development of sustainable supply chain management in the textile and apparel industry. In this paper, by Shen, et. al in the year 2017, fifteen articles were reviewed, and the findings were abridged in the area of textile and apparel sustainable supply chain management.

This study by Foo, Lee, Tan, and Ooi, in 2018, aims to analytically assess whether the application of selected green supply chain management (GSCM) practices will drive and allow sustainability among ISO14001-certified manufacturing firms in Malaysia. Besides this, the importance and strength of the relationships between GSCM practices and sustainability performance were also investigated and afterwards ranked using a two-stage PLSANN approach. PLS-SEM using SmartPLS 3.0 and artificial neural network analysis (ANN) helped as statistical analysis tools.

This paper shows the supply chain practices of China's garment industries. It has shown how the supply chain practices have reduced carbon footprint. The Chinese government has come up with strict regulatory systems to reduce carbon emission and it has also put a limitation on the amount of energy that factories can consume. The authors aim to examine how the energy consumption constraint affects the optimal decisions of the supply chain members and address the supply chain coordination issue.

This paper by Kouhizadeh, and Sarkis, in 2018, seeks to help advance the discussion and motivate additional practice and research related to green supply chains and blockchain technology. The paper's main emphasis was recognizing potential uses across the range of green supply chain management functions and activities, precisely on environmental sustainability in the supply chain.

The purpose of this paper, by Majumdar and Sinha, in 2018, is to find out the barriers of green supply chain management in the textile SMEs of India. The most important barriers that have been revealed are complexity of green process and system design (CGD) and lack of support from regulatory authorities (SRA). Thus, the paper recommends, that immense consideration should be paid by textile SMEs, in using resources to overcome the significant barriers like complexity of green process and system design (CGD).

This paper, by Majumdar and Sinha in 2019, makes the attempt to find out the vital barriers of green textile and apparel supply chain management in Southeast Asian countries. Through literature review and questionnaire survey, twelve important barriers have been recognized. The paper recommends that it is necessary for the garment industries to remove the root causes of the barriers in order to save the environment. The paper also claims that green technological innovation, consumers' awareness and support of the regulatory bodies should be introduced for effective application of green supply practices in textile and apparel supply chains.

The aim of Stremlau and Tao's paper of 2016, is to deliver a summary of the factors that allow or magnify the implementation of a GSCM strategy for textile and fashion companies. Furthermore, the paper examined how textile and fashion companies see their incentives of applying GSCM and what their organizational reactions 
regarding the perceived barriers and enablers look like.

Purchasing is the central of production, which has a crucial link to carbon emission. Precise purchasing decisions inflict directly on supply chain operations and carbon emission of the whole corporation. Taking carbon emission into account, the paper written by Liu, Wang, and Bao, in 2016, builds an improved purchase model of multi objective mixed integer programming that includes several suppliers and several purchased products and that is limited by purchase cost, quality and delay. The paper also offers cases to scrutinize the impact of carbon emission on optimized purchase decisions of corporations.

It is seen that the supply chains of the industries of Bangladesh is not effective enough to achieve environmental sustainability. Earlier studies on environmental sustainability have not drew clear plans to attain sustainability across supply chains, mainly in the setting of emerging economies and have been of limited significance in situations outside the geographical region of their focus. To address these gaps, the authors, Suhi, Enayet, Haque, Ali, Moktadir, and Paul have done a study in 2019. The study suggested a best worst method (BWM) as a framework to evaluate the environmental standards for sustainability in selected industries in Bangladesh.

Due to the pressure received from markets, regulations and competitors, companies have implemented green supply chain management (GSCM). Unfortunately, several GSCM practices exist, thus, companies are not sure which GSCM practice to follow. The aim of this paper, by Zhu, Sarkis, and Lai, in 2019, is to develop models that can be helpful for companies to identify right GSCM practices and implement GSCM effectively and efficiently. This paper offers a three-step method for companies to decide activities for greening their chains.

In todays' competitive environment, organizations have come up with supply chain sustainability practices to achieve a long-term economic success. However, there is a misalignment between sustainable practices and organizations' strategies and capabilities, particularly when sustainability requirements of the stakeholders changes over time. This study by Chowdhury, Agarwal and Quaddus, (2019), develops a decision support (DS) framework for supply chain sustainability (SCS) that finds and ranks optimal strategies for SCS in a dynamic environment. The SCS DS framework provides an enhanced conceptual understanding of the changes in stakeholder requirements and with the help of this DS framework, managers would be able to change their SCS practices according to the stakeholders' demands and at the same time balance the economic, social and environmental feasibility concurrently.

According to the literature review, it is seen that the most significant barrier is that there is low demand from customers, lack of customer support and financial limitation due to short term little financial benefit to businesses, with absence of government regulations also a commonly faced barrier in adopting green supply chain initiatives. It is crucial for garments factories of Bangladesh to overcome these barriers because without correct management of the supply chain, only wage competitiveness cannot safeguard sustainable business. So, for the sake of the sector, Ready Made Garments has no substitute to making the SCM effective. It is also found that Knowledge Management Capability (KMC) can play a role in strengthening supply chains of factories. $\mathrm{KMC}$ is an intuitive resource of a firm that can bring sustainable performance through Green Supply Chain Management (GSCM) practices. And it also places the basis for the managers, practitioners, and researchers to highlight the significance of GSCM practice to develop sustainability performance. This development in Green Supply Chain Management necessitates time as it needs vital change in the methods company design, procure, manufacture, distribute, dispose and recycle their products.

\section{Research Method}

The research is qualitative and is based on primary research as the data used here are all primary data collected through surveys, whose respondents are mid-level managers of Supply Chain Management department of garment factories. The top 60 readymade garment factories of Gazipur were chosen and mid-level SCM manager was surveyed from each factory. This sample size is taken to limit the scope of the study. The intention of the research is to reveal the types of supply chain managerial practices that garment factories of Bangladesh implement. The dependent variable will be 'Environmental Sustainability' and the independent variables that will be used here are green procurement, green manufacturing, green distribution and green logistics/transportation. 


\begin{tabular}{|c|c|}
\hline Determinants & Explanation \\
\hline Environmental Sustainability (ES) & $\begin{array}{l}\text { This variable will be measured based on the rate of recycled } \\
\text { products that Bangladesh's garment factories produce. The } \\
\text { international benchmark of rate of recycled products is } 45 \% \text { of the } \\
\text { total production of garments. So, in this research a factory will be } \\
\text { considered environmentally sustainable, only when its rate of } \\
\text { recycled products is equal or more than } 45 \% \text { of the total garments } \\
\text { produced. }\end{array}$ \\
\hline Green Procurement (GP) & $\begin{array}{l}\text { Is one of the supply-side practices based on which suppliers are } \\
\text { chosen. Suppliers are chosen depending on their environmental } \\
\text { competence, technical and eco-design capability, environmental } \\
\text { performance, etc. }\end{array}$ \\
\hline Green Manufacturing (GM) & $\begin{array}{l}\text { Manufacturers manufacture products in a way that help to reuse, } \\
\text { recycle and recover parts and material components of the product; } \\
\text { avoid or reduce the use of materials, which will harm the } \\
\text { environment, within production process; etc. }\end{array}$ \\
\hline Green Distribution (GD) & $\begin{array}{l}\text { A type of packaging that makes the attempt to (1) downsize } \\
\text { packaging, (2) use "green" packaging materials, (3) promote } \\
\text { recycling and reuse programs, etc. }\end{array}$ \\
\hline Green logistics/transportation (GL) & $\begin{array}{l}\text { Is about delivering goods directly to user site, using alternative fuel } \\
\text { vehicles and grouping orders together, etc. Green logistic is also } \\
\text { about reverse logistic which means that companies will collect used } \\
\text { products and packaging from customers for recycling, returning } \\
\text { packaging and products to suppliers for reuse and so on. }\end{array}$ \\
\hline
\end{tabular}

In this research, for analysis there will be a descriptive data analysis, which will show the mean, standard deviation and the frequency table. For the frequency table, the frequencies will be explained based on the factors. Afterwards, there will be a regression model, through which the researchers will try to find out whether the independent variables have the ability to explain the dependent variable and the degree and pattern of the relationship between environmental sustainability and the dependent variables. Thus the research equation will be:

\section{Analysis of Data and Result}

$$
\mathrm{ES}=\alpha+\mathrm{BGP}+\beta \mathrm{GM}+\beta \mathrm{GD}+\beta \mathrm{GL}
$$

The interview session was conducted among the top managers of 66 garments factory.

Table 1. Respondent information

\begin{tabular}{lll}
\hline Position of respondent & Frequency & Percent \\
\hline Head of operations and supply chain & 3 & $4.5 \%$ \\
General manager, Supply chain & 4 & $6.1 \%$ \\
Supply chain/ logistics manager & 16 & $24.2 \%$ \\
Supply chain \& logistics administrator & 7 & $10.6 \%$ \\
Purchasing manager & 12 & $18.2 \%$ \\
Others & 24 & $36.4 \%$ \\
Total & 66 & $100.0 \%$ \\
\hline
\end{tabular}

From the table 1 we can see most of the respondents includes other position than head of operation and it is $36.4 \%$. After that, almost $25 \%$ respondents are supply chain manager or logistics manager. 
Table 2. Managers familiar with green supply chain management

\begin{tabular}{llll}
\hline & & Frequency & Percent \\
\hline Top managers familiar with Green Supply chain management & No & 26 & $39.4 \%$ \\
& Yes & 40 & $60.6 \%$ \\
The organization uses Green Supply chain management & No & 32 & $48.5 \%$ \\
& Yes & 34 & $51.5 \%$ \\
\hline
\end{tabular}

The table 2 represents more than $60 \%$ mangers are familiar with green supply chain management while almost $39 \%$ managers are not familiar. On the other hand, more than $51 \%$ organizations use green supply chain management and more than $48 \%$ organizations do not use it.

\begin{tabular}{lll}
\hline Reason of the failure in establishing environmental sustainability & & Percentage \\
\hline Lack of education and training on implementing green thinking & Frequency & $9.1 \%$ \\
High cost associated with green procurement & 6 & $51.5 \%$ \\
Lack of knowledge and information & 34 & $37.9 \%$ \\
Lack of govt. initiatives for GSCM practitioners & 25 & $1.5 \%$ \\
Total & 1 & $100.0 \%$ \\
\hline
\end{tabular}

From the table, it is visible that almost $52 \%$ respondent think that high cost is an important reason of failure in establishing environmental sustainability. Additionally, almost 38\% think that lack of knowledge and information is making hindrance to establish environmental sustainability.

Table 3. Level of importance of motivations with respect to the implementation of the GSCM practices by the organization

\begin{tabular}{lllll}
\hline & \multicolumn{2}{l}{ Encouragement from organization } & \multicolumn{2}{l}{ Competitive pressure } \\
& Frequency & Percentage & Frequency & Percentage \\
\hline Unimportant & 0 & 0 & 1 & $1.5 \%$ \\
Little important & 15 & $22.7 \%$ & 3 & $4.5 \%$ \\
Moderately important & 13 & $19.7 \%$ & 15 & $22.7 \%$ \\
Important & 26 & $39.4 \%$ & 27 & $40.9 \%$ \\
Very important & 12 & $18.2 \%$ & 20 & $30.3 \%$ \\
Total & 66 & $100.0 \%$ & 66 & $100.0 \%$ \\
\hline
\end{tabular}

From the table 3 , it has been seen that around $40 \%$ respondents consider motivation from organization as important while almost $41 \%$ respondents consider competitive pressure as important.

Table 4. Achievement of the organization during the past year

\begin{tabular}{|c|c|c|c|c|c|c|}
\hline & \multicolumn{2}{|c|}{$\begin{array}{l}\text { Job Descriptions specify health and } \\
\text { safety task and environmental impact } \\
\text { related roles }\end{array}$} & \multicolumn{2}{|c|}{$\begin{array}{l}\text { Employment interview is tailored to } \\
\text { gauge the potential compatibility of } \\
\text { the candidate with the company's } \\
\text { green goals }\end{array}$} & \multicolumn{2}{|c|}{$\begin{array}{l}\text { New recruits } \text { are provided with } \\
\text { information } \\
\text { development }\end{array}$} \\
\hline & Frequency & Percentage & Frequency & Percentage & Frequency & Percentage \\
\hline Never & 5 & $7.6 \%$ & 18 & $27.3 \%$ & 18 & $27.3 \%$ \\
\hline Rarely & 2 & $3.0 \%$ & 5 & $7.6 \%$ & 5 & $7.6 \%$ \\
\hline Sometimes & 27 & $40.9 \%$ & 20 & $30.3 \%$ & 20 & $30.3 \%$ \\
\hline Very often & 24 & $36.4 \%$ & 13 & $19.7 \%$ & 13 & $19.7 \%$ \\
\hline Always & 8 & $12.1 \%$ & 10 & $15.2 \%$ & 10 & $15.2 \%$ \\
\hline Total & 66 & $100.0 \%$ & 66 & $100.0 \%$ & 66 & $100.0 \%$ \\
\hline
\end{tabular}

Almost $41 \%$ organization include sometimes on their job descriptions with the specification of health and safety 
task and environmental impact related roles. It is a good sign that almost $36 \%$ organization do this task very often. $30 \%$ organization sometimes tailored to gauge the potential compatibility of the candidate with the company's green goal in case of employment interview. Additionally, it is a matter of concern that in case of $27 \%$ organization, they did not take such type of initiative. New recruits are provided with information about sustainable development policies and commitments sometimes in case of almost only $30 \%$ case and never for $27 \%$ cases.

Table 5. Reliability statistics

\begin{tabular}{ll}
\hline Cronbach's Alpha & N of Items \\
\hline .948 & 26 \\
\hline
\end{tabular}

Cronbach's alpha values are presented in Table 5 According to Cronbach LJ (1951), internal reliability is achieved when the Cronbach's Alpha value is 0.6 or higher. In our analysis, the Cronbach's Alpha is greater than 0.60 which is 0.948 , so that all variables are inferred in our study. Therefore, all the variables in this study are reliable and can be used for quantitative analysis.

Table 6. KMO and Bartlett's test

\begin{tabular}{lll}
\hline \multicolumn{2}{l}{ Kaiser-Meyer-Olkin Measure of Sampling Adequacy. } & .788 \\
\hline \multirow{3}{*}{ Bartlett's Test of Sphericity } & Approx. Chi-Square & 2053.987 \\
& Df & 325 \\
& Sig. & .000 \\
\hline
\end{tabular}

Before factor analysis, data adequacy is to be tested to make sure that these data are adequate for factor analysis. KMO (Kaiser-Mayer-Oikin) test was run that varies from 0 to 1 . A score closer to 1 indicates the higher accuracy of the data. A KMO score of more than $0.9,0.8,0.7,0.6$ and 0.5 indicates marvelous, meritorious, middling, mediocre and miserable respectively (George and Mallary, 2011).

Bartlett test of sphericity measures the normality of the distribution. A significance value, $\mathrm{p}<0.05$ indicates that these data will not produce identity matrix and hence acceptable for factor analysis (George and Mallary, 2011).

The null hypothesis, that the population correlation matrix is an identity matrix, is rejected by Bartlett's Test of Sphericity. The approximate chi-square statistics is 2053.987 with 325 degrees of freedom, which is significant at the .05 level. The value of KMO statistic (.788) is also larger (>.05). Thus, factor analysis is considered an appropriate technique for analyzing the correlation matrix. 
Table 7. Rotated component matrix

\begin{tabular}{|c|c|c|c|c|c|}
\hline \multicolumn{6}{|l|}{ Rotated Component Matrix ${ }^{a}$} \\
\hline & \multicolumn{5}{|c|}{ Component } \\
\hline & 1 & 2 & 3 & 4 & 5 \\
\hline Green_manufacture_1 & .839 & & & & \\
\hline Green_manufacture_2 & .851 & & & & \\
\hline Green_manufacture_3 & .873 & & & & \\
\hline Green_procurement_1 & & .873 & & & \\
\hline Green_procurement_3 & & .924 & & & \\
\hline Green_procurement_4 & & .915 & & & \\
\hline Green_distribution_3 & & & .781 & & \\
\hline Green_distribution_4 & & & .768 & & \\
\hline Green_distribution_5 & & & .872 & & \\
\hline Green_logistic_2 & & & & .809 & \\
\hline Green_logistic_3 & & & & .813 & \\
\hline Green_logistic_4 & & & & .868 & \\
\hline Use_IT_2 & & & & & .875 \\
\hline Use_IT_3 & & & & & .883 \\
\hline Use_IT_5 & & & & & .857 \\
\hline Use_IT_6 & & & & & .863 \\
\hline \multicolumn{6}{|c|}{ Extraction Method: Principal Component Analysis. } \\
\hline \multicolumn{6}{|c|}{ Rotation Method: Varimax with Kaiser Normalization. } \\
\hline a. Rotation converged in 8 iterat & & & & & \\
\hline
\end{tabular}

The extracted factor pattern matrix represents how the observed variables are weighted with each of the factors and correlation between the variables and the factors. Higher correlation value indicates higher involvement with the respective factor. As it is said, the factors are made by the function of observed items by removing the clutter of low correlations (those are less than 0.05 ) that are not significant.

With the help of Exploratory factor analysis (EFA) techniques, it has seen by (table no 7) to be deleted some items because factor loading less than 0.5 did not consider or reproduce. Highest loading indicates the relative significance of the item that were used to build up the respective construct. At the initial stage of the study we have started with 26 items under 5 variables. After using factor analysis tool, 16 items will be considered for our next step which is regression analysis.

The dependent variable is the environmental sustainability of an organization and the independent variables are the 5 variables: green procurement, green manufacturing, green distribution, green logistics, use of IT for supply chain management.

Table 8. Model summary

\begin{tabular}{llll}
\hline $\mathrm{R}$ & $\mathrm{R}$ Square & Adjusted R Square & Std. Error of the Estimate \\
\hline $.700^{\mathrm{a}}$ & .690 & .580 & .458 \\
\hline
\end{tabular}

Note. a. Predictors: (Constant), Use_IT, Green_manufacturing, Green_logistic, Green_procurement, Green_distribution.

By the analyzing above table 8 , the value of $\mathrm{R}$ is found to be 0.700 which is greater than .50 and the value indicates high degree of positive relationship (Malhotra \& Dash, 2011) in between dependent and independent variable. The value of $\mathrm{R}^{2}$ indicates the variation explained by the independent variable. Here, in this study $\mathrm{R}^{2}$ is found to be 0.69 and therefore, environmental sustainability can be found to explain $69 \%$ variation in the green supply chain management. Another measure, the adjusted $\mathrm{R}^{2}$ indicates the goodness of fit for regression model. If the gap between $\mathrm{R}^{2}$ and adjusted $\mathrm{R}^{2}$ are lower, then it can be asserted that the number of non-significant variables is minimal in a model. In this study, the difference between $\mathrm{R}^{2}$ and adjusted $\mathrm{R}^{2}$ is low. This indicates that the number of independent variables used in this model significantly contribute explaining the dependent variable. 


\begin{tabular}{lllllll}
\hline $\begin{array}{lllll}\text { ANOVA } \\
\text { Model }\end{array}$ & & Sum of Squares & df & Mean Square & F & Sig. \\
\hline \multirow{2}{*}{1} & Regression & 21.305 & 5 & 4.261 & 20.292 & $.000^{\mathrm{b}}$ \\
& Residual & 12.581 & 60 & .210 & & \\
& Total & 33.886 & 65 & & & \\
\hline
\end{tabular}

Note. a. Dependent Variable: Environmental sustainability

b. Predictors: (Constant), Use_IT, Green_manufacturing, Green_logistics, Green_procurement, Green_distribution

In this study, the null hypothesis may be rejected as the significance level has been found to be less than 0.05 $(0.000<.05)$. Hence, green supply chain management have positive association with the environmental sustainability.

\begin{tabular}{|c|c|c|c|c|c|c|}
\hline \multicolumn{7}{|c|}{ Coefficients $^{a}$} \\
\hline \multirow{2}{*}{\multicolumn{2}{|c|}{ Model }} & \multicolumn{2}{|c|}{ Unstandardized Coefficients } & \multirow{2}{*}{$\begin{array}{l}\text { Standardized } \\
\text { Coefficients } \\
\text { Beta }\end{array}$} & \multirow[t]{2}{*}{$\mathrm{t}$} & \multirow[t]{2}{*}{ Sig. } \\
\hline & & $\mathrm{B}$ & Std. Error & & & \\
\hline \multirow{6}{*}{1} & (Constant) & .100 & .291 & & .344 & .732 \\
\hline & Green_manufacturing & -.189 & .373 & -.066 & -.507 & .614 \\
\hline & Green_procurement & .321 & .156 & .282 & 2.053 & .044 \\
\hline & Green_distribution & .028 & .105 & .043 & .266 & .791 \\
\hline & Green_logistics & .137 & .069 & .266 & 1.975 & .043 \\
\hline & Use_IT & -.021 & .054 & -.059 & -.396 & .693 \\
\hline
\end{tabular}

Note. a. Dependent Variable: Environmental sustainability.

The study dealt with all the 16 items of the said five dimensions and they are: Green manufacturing, Green procurement, Green Distribution, Green logistics and Use of IT.

The multiple regression model can be written as follows:

Environmental suitability $=\beta_{0}+\beta_{1} \times$ Green manufacturing $+\beta_{2} \times$ Green procurement $+\beta_{3} \times$ Green Distribution $+\beta_{4} \times$ Green logistics $+\beta_{5} \times$ Use of IT

Using the values from the given coefficients table, the regression model for environmental sustainability becomes the following:

Environmental suitability $=0.1-0.189 \times$ Green manufacturing $+0.321 \times$ Green procurement $+0.028 \times$ Green Distribution $+0.137 \times$ Green logistics $-0.021 \times$ Use of IT

From the multiple regression model, we can see that green manufacturing and use of IT have reverse impact on the establishment of environmental sustainability for the selected organization. From the t-test result we found Green procurement and Green logistic as a significant variable since p-value is less than 0.05 as the significance level is $5 \%$.

\section{Findings}

Green manufacturing is negatively related to environmental sustainability, which can be seen from its t-value -0.507 . However, the relation is not statistically significant with a p-value of 0.614 . Companies are now seen to implement green manufacturing such as, designing products in a way that will help to recycle and reuse the products, producing products by avoiding hazardous products, etc. However, the normal public of Bangladesh does not have the level of education to understand the reuse and recycle of products. Most products are thrown away as waste, which is not well managed by the government. Besides, there were no specific places where products can be stored for recycling. Yet, nowadays, many public buildings keep bins where different sort of products can be stored for recycling.

Green procurement has a strong positive impact on environmental sustainability. And the relation is statistically significant with a value of 0.044 which is less than 0.05 . Garment factories nowadays, choose suppliers of raw materials based on their performance and competence regarding environmental sustainability. These types of steps were mainly taken due to the pressure from international companies, otherwise they will stop taking goods 
from the garment factories. So attempts by garment factories to comply with environmental sustainability standards, is nowadays noticeable.

Green distribution has a weak positive relation and it is not also significantly statistic. Garment factories have been seen to use green packaging materials and promote reuse and recycling of products. However, due to the public's unawareness and low level of education, products are not managed in the way that will help to conserve the environment. Yet, some positive changes are taking place, which has positively impacted environmental sustainability.

Green logistics has a strong and positive impact on environmental sustainability and also the relation is significantly strong. It has a p-value of 0.043 . Factories distribute their garments in big slots to sites. Besides, there are many individuals and small shop owners who accumulate old clothes and pieces of fabrics and recycle and reuse them and sell them at a lower cost. However, these shops are considered illegal by government and no steps are taken from government to protect these shop owners and their tasks. Thus, there are not much initiatives from the government to make the environment sustainable.

\section{Conclusion}

Environmental sustainability, nowadays is one of the hot topics that is been discussed in many studies and researches. These studies have always shown that it is high time for governments and related institutions to show concern for the environment. One way of conserving the environment is by implementing supply chain managerial practices with greening the environment. Implementing these green supply chain managerial practices is a hardship for factories. Thus researches and studies are undertaken to view the reasons for the hardship.

After researching the relationship between Green Supply Chain Managerial practices and Environmental Sustainability, it is seen that overall, GSCM practices has a positive impact on Environmental Sustainability. GSCM practices are categorized as Green manufacturing, Green procurement, Green distribution and Green logistics. From the research it is revealed that only green manufacturing has a negative impact on the sustainability of environment.

\section{References}

Ahmed, S., Akter, T., \& Ma, Y. (2018). Green Supply Chain Management (GSCM) Performance Implemented by the Textile Industry of Gazipur District, Dhaka. Logistics, 2(4), 21.

Al Mamun, M. A. (2019). An Analysis of Employee Awareness on Green Human Resource Management Practices: Evidence from Bangladesh. Human Resource Management Research, 9(1), 14-21, https://doi.org/10.5923/j.hrmr.20190901.03

Bouzon, M., \& Govindan, K. (2015). Reverse logistics as a sustainable supply chain practice for the fashion industry: an analysis of drivers and the Brazilian Case. In Sustainable fashion supply chain management (pp. 85-104). Springer, Cham.

Chowdhury, M. M. H., Agarwal, R., \& Quaddus, M. (2019). Dynamic capabilities for meeting stakeholders' sustainability requirements in supply chain. Journal of Cleaner Production, 215, 34-45. https://doi.org/ https://doi.org/10.1016/j.jclepro.2018.12.222

Foo, P. Y., Lee, V. H., Tan, G. W. H., \& Ooi, K. B. (2018). A gateway to realising sustainability performance via green supply chain management practices: a PLS-ANN approach. Expert Systems with Applications, 107, 1-14, https://doi.org/10.1016/j.eswa.2018.4.013

Habib, A., \& Bao, Y. (2019). Impact of knowledge management capability and green supply chain management practices on firm performance. International Journal of Research in Business and Social Science, 8(6), 240-255. https://doi.org/10.20525/ijrbs.v8i6.548

Hong, J., Zhang, Y., \& Ding, M. (2018). Sustainable supply chain management practices, supply chain dynamic capabilities, and enterprise performance. Journal of Cleaner Production, 172, 3508-3519. https://doi.org/10.1016/j.jclepro.2017.06.093

Hossain, M. U., \& Roy, I. (2016). Supply chain management for sustainable RMG growth in Bangladesh. International Journal of Science and Research, 5(4), 1242-1248.

Köksal, D., Strähle, J., Müller, M., \& Freise, M. (2017). Social sustainable supply chain management in the textile and apparel industry-A literature review. Sustainability, 9(1), 100. https://doi.org/10.3390/su9010100 
Kouhizadeh, M., \& Sarkis, J. (2018). Blockchain practices, potentials, and perspectives in greening supply chains. Sustainability, 10(10), 3652. https://doi.org/10.3390/su10103652

Liu, C., Wang, Y., \& Bao, X. (2016). Optimized Purchase Decisions towards Low Carbon Supply Chain. Rev. Técnica Fac. Ing. Univ. del Zulia, 39(2), 62-68.

Majumdar, A., \& Sinha, S. (2018). Modeling the barriers of green supply chain management in small and medium enterprises: A case of Indian clothing industry. Management of Environmental Quality: An International Journal, 29(6), 1110-1122.

Majumdar, A., \& Sinha, S. K. (2019). Analyzing the barriers of green textile supply chain management in Southeast Asia using interpretive structural modeling. Sustainable Production and Consumption, 17, 176-187. https://doi.org/10.1016/j.spc.2018.10.005

Shen, B., Li, Q., Dong, C., \& Perry, P. (2017). Sustainability issues in textile and apparel supply chains. Sustainability, 9. https://doi.org/10.3390/su9091592

Stremlau, K., \& Tao, J. (2016). Green Supply Chain Management Enablers and Barriers in Textile Supply Chains: What factors enable or aggravate the implementation of a GSCM strategy for textile and fashion companies?

Suhi, S. A., Enayet, R., Haque, T., Ali, S. M., Moktadir, M. A., \& Paul, S. K. (2019). Environmental sustainability assessment in supply chain: An emerging economy context. Environmental Impact Assessment Review, 79, 106306. https://doi.org/10.1016/j.eiar.2019.106306

Tumpa, T. J., Ali, S. M., Rahman, M. H., Paul, S. K., Chowdhury, P., \& Khan, S. A. R. (2019). Barriers to green supply chain management: An emerging economy context. Journal of Cleaner Production, 236, 117617. https://doi.org/10.1016/j.jclepro.2019.117617

Yadlapalli, A., Rahman, S., \& Gunasekaran, A. (2018). Socially responsible governance mechanisms for manufacturing firms in apparel supply chains. International Journal of Production Economics, 196, 135-149. https://doi.org/10.1016/j.ijpe.2017.11.016

Zhu, Q., Sarkis, J., \& Lai, K. H. (2019). Choosing the right approach to green your supply chains. Modern Supply Chain Research and Applications. Emerald, 1(1), 54-67. https://doi.org/10.1108/MSCRA-02-2019-0006

\section{Copyrights}

Copyright for this article is retained by the author(s), with first publication rights granted to the journal.

This is an open-access article distributed under the terms and conditions of the Creative Commons Attribution license (http://creativecommons.org/licenses/by/4.0/). 